\title{
The Corrosion Resistance of Nitrogen Bearing Martensitic Stainless Steels
}

\author{
Alberto Akikazu ONO, Neusa ALONSO and Andre Paulo TSCHIPTSCHIN \\ Department of Metallurgy and Materials Engineering, University of São Paulo, Av. Prof. Mello Moraes, 2463-CEP 05508-900, \\ São Paulo, Brazil.
}

(Received on September 7, 1995; accepted in final form on January 18, 1996)

\begin{abstract}
It has been mentioned that nitrogen enhances the corrosion resistance of the martensitic stainless steels. In this work, by means of electrochemical and mass loss tests, the corrosion resistance of three experimental martensitic stainless steels, with partial substitution of carbon by nitrogen were investigated. Martensitic stainless steels type AISI 410 and AISI 420 were also tested, for comparison, and all steels were tested in both hardened and tempered conditions.

The resistance to general corrosion in $0.5 \mathrm{M} \mathrm{H}_{2} \mathrm{SO}_{4}$ was evaluated by mass loss tests and by potentiodynamic polarization tests, the last through the critical current density and the passive current density. The resistance to pitting corrosion was evaluated by potentiodynamic polarization tests in $0.01 \mathrm{M} \mathrm{NaCl}+0.01 \mathrm{M} \mathrm{Na}_{2} \mathrm{SO}_{4}$, through the pitting potential.

The results of both general corrosion and pitting corrosion tests show that the nitrogen, when present in the solid solution condition, improves the corrosion resistance. It was observed that with the partial substitution of carbon by nitrogen, the passive current densities were lower, in $0.5 \mathrm{M} \mathrm{H}_{2} \mathrm{SO}_{4}$, and the pitting potentials were higher, in the $0.01 \mathrm{M} \mathrm{NaCl}+0.01 \mathrm{M} \mathrm{Na}_{2} \mathrm{SO}_{4}$ solution.

The results are discussed basically through the different chemical composition of the steels and the microstructure observed in each sample.
\end{abstract}

KEY WORDS: martensitic stainless steel; nitrogen; general corrosion; pitting corrosion.

\section{Introduction}

The nitrogen, as an alloying element, is well known to improve the resistance to pitting corrosion of the austenitic stainless steels. ${ }^{1)}$ The same behavior has been reported on martensitic stainless steels, ${ }^{2)}$ and the partial substitution of the carbon by nitrogen in those steels seems to improve both the mechanical properties and the corrosion resistance. ${ }^{2-4)}$ Although the mechanism by which the nitrogen improves the corrosion resistance is not well understood, theories have been developed, mainly for austenitic stainless steels, ${ }^{5-8)}$ and some of them report a synergy between nitrogen and molybdenum.

The present work deals with corrosion studies on experimental martensitic stainless steels, with partial substitution of carbon by nitrogen, and also on commercial grades AISI 410 and AISI 420 steels. The steels were tested in both hardened and tempered conditions. The resistance to general corrosion in $0.5 \mathrm{M}$ $\mathrm{H}_{2} \mathrm{SO}_{4}$ was evaluated by mass loss tests and by potentiodynamic polarization tests, the last through the critical current density and the passive current density. The resistance to pitting corrosion was evaluated by potentiodynamic polarization tests in $0.01 \mathrm{M} \mathrm{NaCl}+$ $0.01 \mathrm{M} \mathrm{Na}_{2} \mathrm{SO}_{4}$, through the pitting potential.

\section{Experimental}

The composition of the steels referred to in this paper is given in Table 1. The total amount of interstitial elements, in the experimental alloys $\mathrm{A}, \mathrm{B}$ and $\mathrm{C}$, were provided to be similar to the type AISI 420 steel.

The steels were cut into various coupon sizes, and heat treatments, corresponding to the quenched condition $\left(1000^{\circ} \mathrm{C}\right)$ and quenched and tempered condition $\left(500^{\circ} \mathrm{C} / 1 \mathrm{~h}\right)$ were performed.

The measurement of potentiodynamic polarization curves was performed in a glass cell. The working electrodes consisted of metallic samples embedded in an epoxy resin and offering an exposed area of at least $1 \mathrm{~cm}^{2}$. The samples were ground up to $\# 600$ emery

Table 1. Chemical composition of steels. (mass\%) Fe Bal.

\begin{tabular}{|c|c|c|c|c|c|c|c|c|}
\hline Steel & Cr & C & $\mathbf{N}$ & $\mathrm{Ni}$ & $\mathbf{M n}$ & $\mathrm{Si}$ & $\mathbf{P}$ & $\mathbf{S}$ \\
\hline A & 15.8 & 0.13 & 0.19 & 0.11 & 0.017 & 0.135 & 0.010 & 0.010 \\
\hline B & 14.8 & 0.16 & 0.16 & 0.11 & 0.017 & 0.079 & 0.020 & 0.010 \\
\hline C & 13.0 & 0.11 & 0.17 & - & 0.39 & 0.40 & 0.0125 & 0.004 \\
\hline AISI 410 & 13.4 & 0.12 & - & - & 0.57 & 0.25 & 0.030 & 0.010 \\
\hline AISI 420 & 12.6 & 0.33 & 0.02 & 0.23 & 0.35 & 0.24 & 0.026 & 0.018 \\
\hline
\end{tabular}


paper prior to the tests, the scanning rate was $1 \mathrm{mV} \cdot \mathrm{s}^{-1}$ and a platinum sheet was used as the counter electrode. The saturated calomel electrode (SCE) was used as the reference electrode, and all potentials measurements in the text refer to the SCE.

The mass loss tests were performed in open flasks with $400 \mathrm{ml}$ of the testing solution, and the metallic samples were ground up to $\$ 600$ emery paper prior to the immersion.

Both electrochemical and mass loss tests were performed at $(24 \pm 2)^{\circ} \mathrm{C}$, all the testing solutions were naturally aerated and there were made at least three tests for each steel and heat treatment.

\section{Results and Discussion}

\subsection{Polarization in $0.5 \mathrm{M} \mathrm{H}_{2} \mathrm{SO}_{4}$}

\subsubsection{Passive Current Density}

The passive current densities, obtained from the polarization curves of the alloys in the quenched (Fig. 1) and in the quenched and tempered (Fig. 2) conditions are presented in Table 2 . From these data, the influence of the chemical composition and of the heat treatment in the passive current density can be observed.

It can be observed that the passive current density decreases with the chromium content in the alloys, being in agreement with the results of other authors. ${ }^{9,10)}$ Also, the interstitial content in the alloys also seems to be important to the passive current density. The results for alloy $\mathrm{C}$ and the steels AISI 410 and AISI 420 suggest that the nitrogen and the carbon have different influences on the passive current density. As the mentioned steels have close chromium content and they differ mainly by the interstitial content, a comparison between them can be easily made. While the AISI 410 and the $\mathrm{C}$ alloy, which have similar carbon content, show similar passive current densities, the AISI 420 is the one which has the highest passive current density and also the highest carbon content. This observation suggests that the nitrogen present in the $\mathrm{C}$ alloy seems not to have great effect on the passive current density of the alloy, and this

Table 2. Passive current densities in $0.5 \mathrm{M} \mathrm{H}_{2} \mathrm{SO}_{4}$.

\begin{tabular}{|c|c|c|}
\hline \multicolumn{3}{|c|}{ Passive current density $\left(\mu \mathrm{A} / \mathrm{cm}^{2}\right)$} \\
\hline Steel & Quenched & Tempered \\
\hline A & $8.4 \pm 0.9$ & $20.0 \pm 1.7$ \\
\hline B & $11.4 \pm 1.3$ & $23.9 \pm 2.8$ \\
\hline C & $12.4 \pm 3.0$ & $23.9 \pm 2.5$ \\
\hline AISI 410 & $13.7 \pm 1.3$ & $34.7 \pm 7.8$ \\
\hline AISI 420 & $42.5 \pm 10.6$ & $173.6 \pm 25.9$ \\
\hline
\end{tabular}
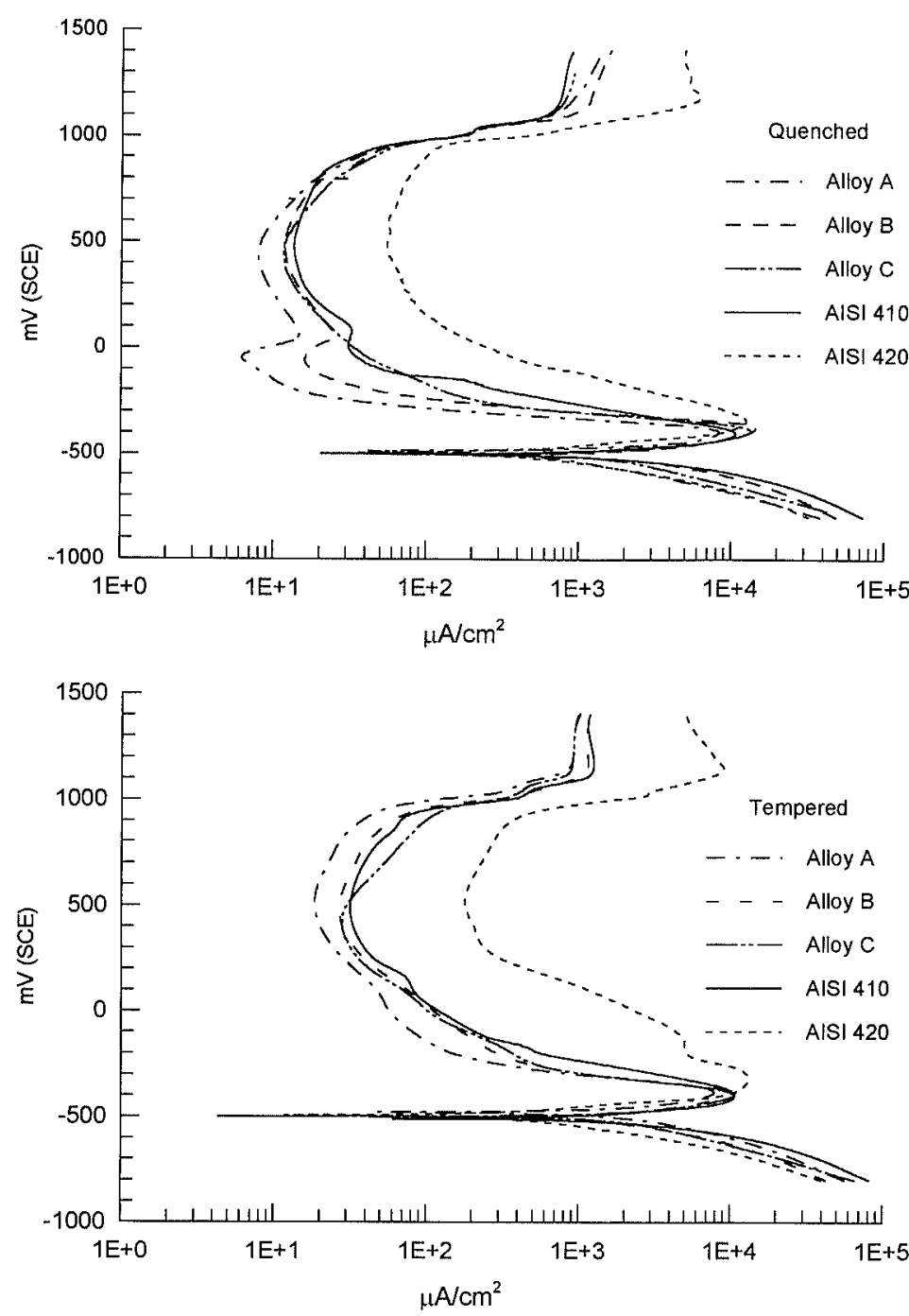

Fig. 1.

Potentiodynamic polarization curves of the steels in the quenched condition, exposed to $0.5 \mathrm{M}$ $\mathrm{H}_{2} \mathrm{SO}_{4}$.
Fig. 2.

Potentiodynamic polarization curves of the steels in the tempered condition, exposed to $5.0 \mathrm{M}$ $\mathrm{H}_{2} \mathrm{SO}_{4}$. 
does not agree with some literature data. ${ }^{2)}$ The difference between the literature data and the results of the present work may be due to the lower nitrogen content of the steels tested in this work $(<0.20 \% \mathrm{~N})$, as well as the lack of molybdenum in the tested steels. After the tempering treatment, the passive current densities of all alloys increase, but it can be observed that the steel with higher carbon content, the AISI 420 , is the one which shows the greatest increase. Moreover, a comparison between the $\mathrm{C}$ alloy, the AISI 410 and AISI 420 shows again that the AISI 410 and the $C$ alloy, which have similar carbon content, show similar passive current densities after tempering. This suggests that the nitrogen is less deleterious in the tempering treatment than the carbon, and this may be due to smaller chromium depleted zones, near by the nitrides or carbonitrides, in comparison with the depleted zones formed next to the chromium carbides.

\subsubsection{Critical Current Density}

The critical current densities, obtained from the polarization curves of the alloys in the quenched (Fig. 1) and in the quenched and tempered (Fig. 2) conditions are presented in Table 3. From these data, the influence of the chemical composition and of the heat treatment on the critical current density can be observed.

In the quenched condition, the behavior of the critical current densities of the tested alloys seems to follow the behavior observed in other chromium alloys, $\left.{ }^{9}\right)$ where they decreased with the increase of the chromium content. However, after the tempering treatment, the composition changes promoted by the precipitation of secondary phases seem to result in different critical current behavior between the nitrogen bearing steels and the AISI 410 and AISI 420 steels.

In the alloys A, B and C, after tempering, the critical current densities are lower than those of the quenched condition, while there is not any noticeable change in the AISI 410 , and in the AISI 420 there is an increase in the critical current density with tempering. The higher critical current densities observed in the only quenched alloys A, B and C, if compared with the alloys in the tempered condition, suggest that the nitrogen, when present in solid solution, increases the critical current density. Although this result is opposite to the ones obtained by some authors ${ }^{2)}$ for martensitic stainless steels, a similar result was obtained for nitrogen bearing duplex stainless steels, by other authors. ${ }^{11}$ )

Table 3. Critical current densities in $0.5 \mathrm{M} \mathrm{H}_{2} \mathrm{SO}_{4}$

\begin{tabular}{|c|c|c||}
\hline \multicolumn{3}{|c|}{ Critical current density $\left(\mathbf{m A} / \mathbf{c m}^{2)}\right)$} \\
\hline Steel & Quenched & Tempered \\
\hline A & $9.7 \pm 1.5$ & $7.7 \pm 0.1$ \\
\hline B & $12.7 \pm 1.6$ & $8.4 \pm 1.1$ \\
\hline C & $11.7 \pm 1.5$ & $9.6 \pm 0.7$ \\
\hline AISI 410 & $10.5 \pm 0.3$ & $10.7 \pm 0.3$ \\
\hline AISI 420 & $12.8 \pm 1.8$ & $14.5 \pm 2.3$ \\
\hline
\end{tabular}

If the assumption that the nitrogen, when present in the solid solution condition, increases the critical current density is valid, its decrease in the alloys A, B and $\mathrm{C}$ after tempering, can be explained by a decrease of the nitrogen content in the matrix promoted by the precipitation of nitrides or carbonitrides. Again, the difference between the literature data ${ }^{23}$ and the results of the present work may be due to the lower nitrogen content of the steels tested in this work, as well as the lack of molybdenum in tested steels.

\subsection{Immersion in $0.5 \mathrm{M} \mathrm{H}_{2} \mathrm{SO}_{4}$}

The mass loss of all alloys in both heat treatment condition, after $120 \mathrm{~min}$ immersion tests in $0.5 \mathrm{M} \mathrm{H}_{2} \mathrm{SO}_{4}$ solution, are shown in Table 4. It can be observed that in the quenched condition, the mass loss increases with the chromium content of the steels, like other $\mathrm{Fe}-\mathrm{Cr}$ alloys tested in this media. ${ }^{12)}$

However, in the tempered condition, the alloys show different corrosion behavior. While the nitrogen bearing alloys $\mathrm{A}, \mathrm{B}$ and $\mathrm{C}$ show higher mass loss in the tempered condition, in the AISI 410 and AISI 420 steels the mass loss is similar in both heat treatment conditions. Again, it seems that the nitrogen present in the alloys $\mathrm{A}, \mathrm{B}$ and $\mathrm{C}$ affect the corrosion behavior of these steels, decreasing the mass loss of the steels when it is present in the solid solution condition. And the increase of the mass loss after tempering can be explained by a decrease in the nitrogen content in the matrix promoted by the precipitation of nitrides or carbonitrides.

\subsection{Polarization in $0.01 \mathrm{M} \mathrm{NaCl}+0.01 \mathrm{M} \mathrm{Na}_{2} \mathrm{SO}_{4}$}

The pitting potential of the alloys in the quenched (Fig. 3) and in the quenched and tempered (Fig. 4) conditions, determined from the polarization curves, are presented in the Table 5. From these data, the influence of the chemical composition and of the heat treatment on the pitting potential can be observed.

Firstly, it can be noted that the pitting potential increases with the chromium content in the alloys. Secondly, as reported by other authors, ${ }^{2)}$ there is a remarkable influence of the nitrogen content on the pitting potential, and this can be easily noted in a comparison between the pitting potentials of the alloy $\mathrm{C}$, and the AISI 410 and AISI 420 steels. Although these steels have similar chromium content, the pitting potential of the alloy $\mathrm{C}$ is by far higher. The importance of the nitrogen content can be observed also through the pitting parameter:

Table 4. Mass loss after $120 \mathrm{~min}$ in $0.5 \mathrm{M} \mathrm{H}_{2} \mathrm{SO}_{4}$.

\begin{tabular}{|c|c|c|}
\hline \multicolumn{3}{|c|}{ Mass loss $\left(\mathrm{mg} / \mathrm{cm}^{2}\right)$} \\
\hline Steel & Quenched & Tempered \\
\hline A & $11.7 \pm 2.8$ & $17.6 \pm 0.1$ \\
\hline B & $10.6 \pm 1.7$ & $13.7 \pm 3.1$ \\
\hline C & $7.0 \pm 0.2$ & $10.6 \pm 0.3$ \\
\hline AISI 410 & $6.3 \pm 0.4$ & $5.7 \pm 0.4$ \\
\hline AISI 420 & $6.9 \pm 0.6$ & $7.6 \pm 0.2$ \\
\hline
\end{tabular}



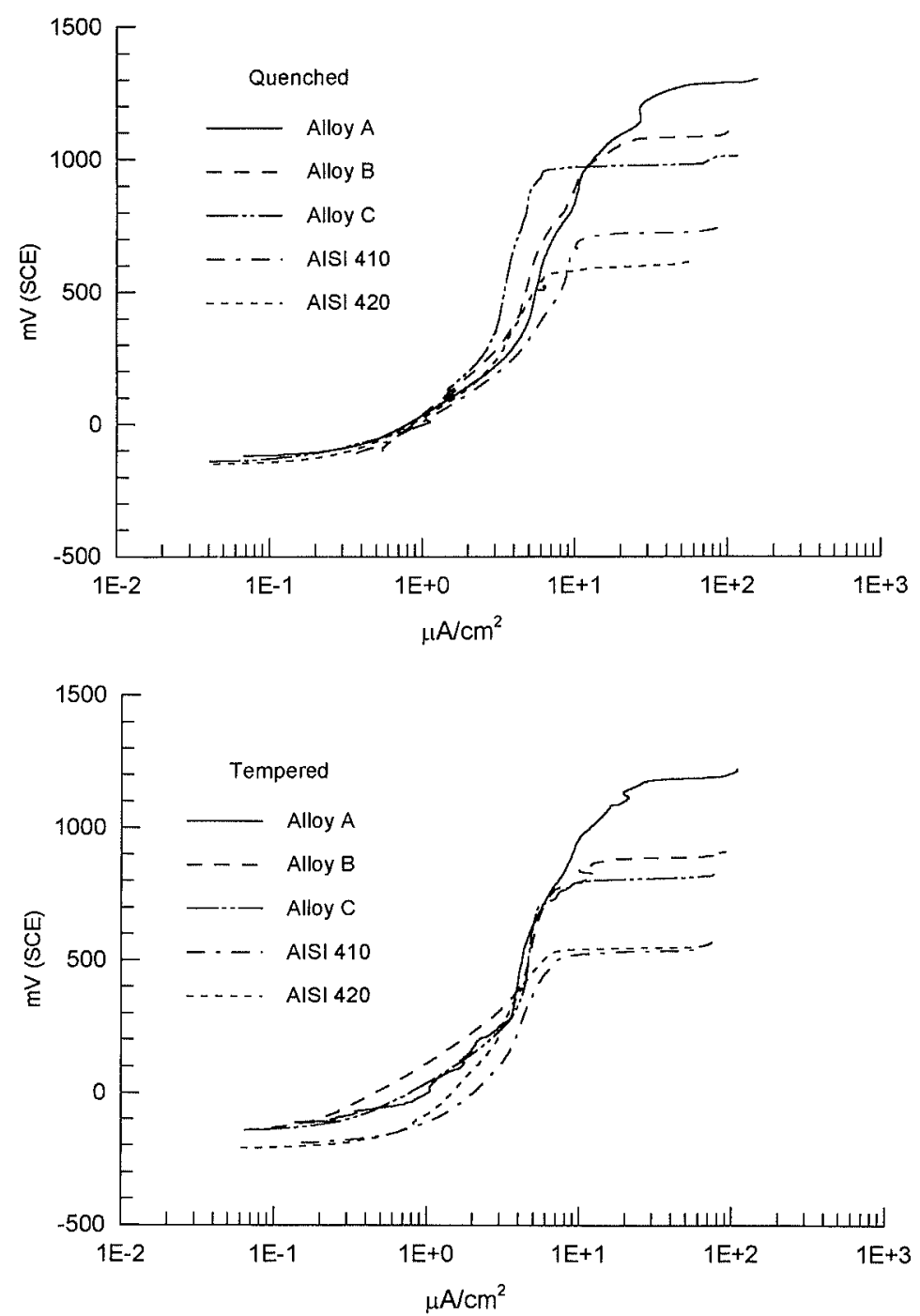

Fig. 3.

Pontentiodynamic anodic polarization curves of the steels in the quenched condition, exposed to $0.01 \mathrm{M} \mathrm{NaCl}+0.01 \mathrm{M} \mathrm{Na}_{2} \mathrm{SO}_{4}$.
Fig. 4.

Potentiodynamic anodic polarization curves of the steels in the tempered condition, exposed to $0.01 \mathrm{M} \mathrm{NaCl}+0.01 \mathrm{M} \mathrm{Na}_{2} \mathrm{SO}_{4}$.

Table 5. Pitting potentials in $0.01 \mathrm{M} \mathrm{NaCl}+$ $0.01 \mathrm{MNa}_{2} \mathrm{SO}_{4}$.

\begin{tabular}{|c|c|c|}
\hline \multicolumn{3}{|c|}{ Pitting Potential (mV } \\
\hline Steel & Quenched & Tempered \\
\hline A & $1182 \pm 26$ & $1146 \pm 71$ \\
\hline B & $1127 \pm 56$ & $846 \pm 48$ \\
\hline C & $984 \pm 140$ & $865 \pm 86$ \\
\hline AISI 410 & $671 \pm 62$ & $601 \pm 72$ \\
\hline AIS1 420 & $547 \pm 18$ & $523 \pm 83$ \\
\hline
\end{tabular}

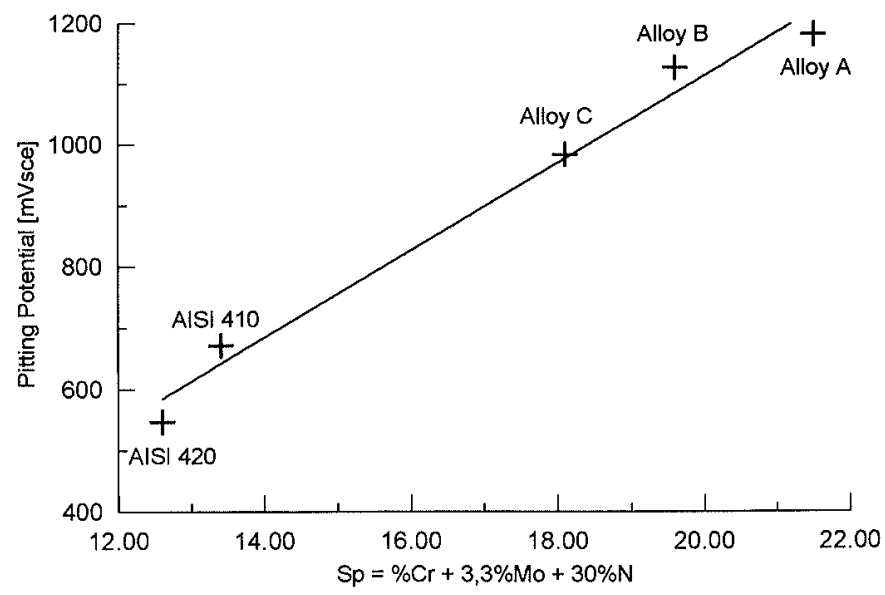

$$
\mathrm{Sp}=\% \mathrm{Cr}+3.3 \% \mathrm{Mo}+X \% \mathrm{~N}
$$

where the nitrogen influence, in this work, leads to an equivalent of $X=30$, as can be seen in Fig. 5. This value of 30 was also reported by other authors ${ }^{2)}$ for high nitrogen martensitic stainless steels, though for higher chloride concentration.

The pitting potential of the tested steels (Table 5) seems to decrease with the tempering treatment. This tendency can be explained, in the nitrogen bearing steels, by the lower pitting corrosion resistance of the chromium depleted zones around the nitrides and carbonitrides, or by a decrease in the nitrogen content

Fig. 5. Pitting potential of the steels in the quenched condition, exposed to $0.01 \mathrm{M} \mathrm{NaCl}+0.01 \mathrm{M} \mathrm{Na}_{2} \mathrm{SO}_{4}$, corresponding to the pitting parameter $\mathrm{Sp}$.

in the matrix promoted by the precipitation. In the commercial steels, the decrease of the pitting potential can be explained by the chromium depleted zones.

\section{Conclusions}

The conclusions of this work are the following:

- the partial substitution of the carbon by nitrogen 
changes the corrosion behavior of the martensitic stainless steels;

- nitrogen does not have great effect on the passive current density of the tested alloys, which have less than $0.20 \% \mathrm{~N}$ and no molybdenum addition;

- nitrogen, when present in solid solution, increases the critical current density of the tested alloys;

- nitrogen increases the pitting potential of the martensitic stainless steels, even without molybdenum addition;

- the tempering treatment of $500^{\circ} \mathrm{C} / 1 \mathrm{~h}$ has an important influence on the corrosion behavior of the martensitic stainless steels.

\section{Acknowledgement}

The authors would like to thank the financial support of the Fundacao de Amparo a Pesquisa do Estado de São Paulo-FAPESP.

\section{REFERENCES}

1) J. E. Truman, M. J. Coleman and K. R. Pirt: Br. Corros. J., 12
(1977), 236

2) H. Berns and J. Lueg: High Nitrogen Steels, ed. by J. Foct and A. Hendry, Inst. Met., London, (1989), 288.

3) P. Gümpel and T. Ladwein: High Nitrogen Steels, ed. by J. Foct and A. Hendry, Inst. Met., London, (1989), 272.

4) M. O. Speidel: High Nitrogen Steels, ed. by J. Foct and A. Hendry, Inst. Met., London, (1989), 92.

5) K. Osozawa and N. Okato: Passivity and Its Breakdown on Iron and Iron-Base Alloys, ed. by R. W. Staehle and H. Okada, NACE, Houston, (1976), 135.

6) R. C. Newman, Y. C. Lu, R. Bandy and C. R. Clayton: Proc. of 9 th Int. Cong. Metallic Corrosion, Nat. Res. Counc., Ottawa, (1984), 394

7) R. C. Newman and T. Shahrabi: Corros. Sci., 27 (1987), 827.

8) C. R. Clayton and K. G. Martin: High Nitrogen Steels, ed. by J. Foct and A. Hendry, Inst. Met., London, (1989), 256.

9) R. Kirchheim, B. Heine, H. Fischmeister, S. Hormann, H. Knote and U. Stolz: Corros. Sci., 29 (1989), 899.

10) J. A. L. Dobbelaar, E. C. M. Herman and J. H. W. De Wit: Corros. Sci., 33 (1992), 765.

11) S. J. Pawel, E. E. Stansbury and C. D. Lundin: Corrosion, 45 (1989), 125

12) Y. H. Yau and M. A. Streicher: Corrosion, 47 (1991), 352. 